\section{A Matrix Machine}

WITH the growing application of matrix algebra, especially in the factorial analysis of psychological data, there is an increasing demand for a machine that will multiply matrices. Such a machine has now been produced in the United States by the International Business Machines Corporation, assisted by a research grant from the Carnegie Foundation, and is described in Psychometrika $(5,289 ; 1940)$. It uses an electric circuit in which one set of connexions is made by special marks on record sheets, one for each row in the first matrix, and the other set by plug wires corresponding to a column of the second matrix. The product of a matrix with any number of rows and up to 15 columns by a second matrix consisting of a single column is thus found, the results being read off on a meter. If the second matrix has more than one column, one column at a time is dealt with. The machine is in use in the psychological laboratory of Dr. L. L. Thurstone of Chicago, and the results appear to be accurate to two significant figures.

\section{The International Seismological Summary}

THe International Seismological Summary for the second quarter of 1934 has just been received. It contains the determinations of 144 epicentres by the workers at Oxford, from all the available evidence sent by seismological observatories. throughout the world. Sixty-two of these epicentres are new and eighty-two are repetitions from old epicentres, again showing the tendency of earthquakes to recur. Fifteen of the earthquakes have deeper focus than normal and one on June 29, 1934, at 8 h. $25 \mathrm{~m} .20 \mathrm{~s}$. G.M.T., has a calculated focus $0 \cdot 106$ of the earth's radius below normal, which is at a greater depth than that of any earthquake previously treated in the summary. The epicentre of this shock was at $6.1^{\circ} \mathrm{S}$., $123.4^{\circ} \mathrm{E}$., which is in the Banda Sea close to and immediately east of the town of Baoebaoe in the island of Celebes in the Dutch East Indies. The area is well known to be frequented by deep focus earthquakes. In view of the accuracy with which the epicentre is known, the numerous data have been used to extend a table of corrections which may be applied to epicentral distances to produce agreement between observed and calculated times of the $P$ wave.

\section{Society of Chemical Industry}

Ar the sixtieth annual meeting of the Society of Chemical Industry, held on July 8, Dr. W. Cullen, the well-known consultant in chemical and metallurgical engineering, was elected president in succession to Prof. J. C. Philip, who has occupied the post for two years. According to the Council's report, membership at the end of 1940 stood at 3,920 , a decrease of only 77 on the total for the previous year; since then, however, many hundreds of new members have joined the Society, a reflection no doubt of the expanding chemical industry of Great Britain. The Society's Medal, the oldest of its distinction, has been awarded to Sir Robert Pickard, director of research for the British Cotton Industry Research
Association at the Shirley Institute, who delivered an address on "The Influence of Science on National Life". The Society is to be congratulated on successfully overcoming the difficulties created by two enforced evacuations by its offices.

\section{Announcements}

Prof. F. A. Lindemann, who had been created a baron (see NATURE, June 21, p. 772), has taken the title of Baron Cherwell, of Oxford in the County of Oxford.

LoRD Horder has been appointed by the Minister of Food to be his personal adviser on medical aspects of food problems.

The first Charles Chree Medal and Prize of the Physical Society will be presented to Prof. S. Chapman, professor of mathematics in the Imperial College of Science and Technology, on July 25. Prof. Chapman will deliver an address on (1) Chree and his work on geomagnetism; (2) geomagnetic time relationships; (3) the future of world magnetic survieying.

Prof. J. B. Conant, president of Harvard University, was elected an honorary fellow of the Royal Society of Edinburgh at a meeting held on July 7 . At the same meeting the Gunning Victoria Jubilee Prize for the period $1936-40$ was presented to Sir James Irvine for his distinguished contributions to organic chemistry; and the Makdougall-Brisbane Prize for the period 1938-40 to Mrs. E. L. Ince, on behalf of her husband, the late Dr. Edward Lindsay Ince, for his papers on "The Periodic Lamé Functions", published in the Proceedings of the Society.

THE Edinburgh Association for Sending Medical Aid to Foreign Countries this year celebrates the centenary of its foundation.

THE following appointments and promotions in the Colonial Service have recently been made: B. de L. Innis (agricultural superintendent, Gold Coast), assistant botanist, British West Indies, Central Sugar Cane Breeding Station, Barbados; J. T. Purvis (senior assistant livestock officer), agricultural officer, Tanganyika Territory.

To promote the interests of science in the south of the United States, a new Southern Association for the Advancement of Science has been organized. Dr. George D. Palmer of the University of Alabama, who served as president during the organizing period, is now secretary-treasurer. Dr. G. H. Boyd of the University of Georgia is president-elect. In addition to the encouragement of scientific research in general and its application to problems of the South in particular, the declared objectives of the new Association include the setting up of a roster of Southern research talent available not only for specific southern problems but also for possible contributions to national defence. 